\title{
NOTES
}

\section{RULE 10b-5 AND REASONABLE RELIANCE: WHY COURTS SHOULD ABANDON FOCUS ON NON-RELIANCE CLAUSES}

\author{
Jonathan P. Altman
}

\section{INTRODUCTION}

In a typical privately negotiated merger or acquisition, the parties involved will be engaged in months of negotiations prior to the closing of their deal. ${ }^{1}$ Over the course of such, many projections, agreements, documents, oral representations and warranties (hereinafter "information") will undoubtedly be exchanged by both sides. In the final purchase agreement, a seller typically lists detailed representations and warranties about its business, and includes a proviso that the buyer is not relying on any other information. ${ }^{2}$ Inclusion of

* University of Pittsburgh, J.D. 2007; Ohio University, B.B.A. 2004. Many thanks to Professor Chuck Cohen for his invaluable guidance, and to Warren Archer for his thoughtful editing.

1. See, e.g., Paramount Commc'ns, Inc. v. Time, Inc., 571 A.2d 1140, 1144 (Del. 1989); Kohls v. Duthie, 766 A.2d 1274, 1281-82 (Del. Ch. 2000).

2. The effect of these "non-reliance clauses" may also be achieved in some circumstances by inclusion of "integration clauses" (i.e., provisions to the effect that the acquisition agreement constitutes the entire and exclusive agreement of the parties with respect to the subject matter thereof). This is because an acknowledgment that the acquisition agreement is exclusive is tantamount to a declaration of nonreliance on extra-contractual representations. The likelihood of an integration clause having such an effect will depend upon the specific language employed. In this regard, an integration clause that specifically references representations and warranties would likely have an effect similar to that of a non-reliance clause, while a more customary reference only to "agreements and understandings" probably would not. 
this "non-reliance clause" (hereinafter "NRC") is intended to restrict a buyer's ability to bring a fraud claim under Rule 10b-5. ${ }^{4}$

Until recently insertion of an NRC into a stock purchase agreement would have, as a matter of law, precluded a finding of reasonable reliance by a sophisticated plaintiff upon any information other than that contained in the parties' definitive agreement. ${ }^{5}$ However, in 2003, the Third Circuit's decision in AES Corp. v. Dow Chemical Co. ${ }^{6}$ concluded that a sophisticated plaintiff may be able to show reasonable reliance on information not included in the final agreement, even where there exists an NRC. ${ }^{7}$ The court reasoned that the enforcement of NRCs to bar any ${ }^{8}$ plaintiff's fraud claims as a matter of law would be inconsistent with Section 29(a) of the Securities Exchange Act of 1934 (hereinafter "Exchange Act"), which forecloses all anticipatory waivers of compliance with the duties imposed by the Act. ${ }^{9}$

This Note will argue that a defendant's inclusion of an NRC is irrelevant for purposes of determining whether a plaintiff's reliance on information not

3. A typical non-reliance clause might read:

Each of the parties is sophisticated and was advised by experienced counsel and, to the extent it deemed necessary, other advisors in connection with this Agreement. Buyer acknowledges that it has performed a comprehensive due diligence investigation of the business and operations of the Company. Each of the parties acknowledges that:

(1) there are no representations or warranties by or on behalf of any party hereto or any of its respective Affiliates or representatives other than those expressly set forth in this Agreement; (2) no party has relied or will rely in respect of this Agreement or the transactions contemplated hereby upon any document or written or oral information previously furnished to or discovered by it or its representatives, other than this Agreement (including the Schedules hereto); and, (3) the parties' respective rights and obligations with respect to this Agreement and the events giving rise thereto will be solely as set forth in this Agreement. The Company and its Affiliates, agents, officers, directors and shareholders will not have or be subject to any liability to Buyer or any other person resulting from the distribution to Buyer, or Buyer's use of, any information not contained in this Agreement (including, without limitation, any offering memorandum provided to Buyer).

Dechert LLP, Rule 10b-5 Claims in Stock Deals: How Much Can You Rely on Your "Non-Reliance" Clause? (July 9, 2003), http://www.dechert.com/library/MA_7-03_SA.pdf.

4. 17 C.F.R. $\S 240.10 b-5$ (2003).

5. See Harsco Corp. v. Segui, 91 F.3d 337, 343 (2d Cir. 1996) (holding that an NRC that is included in "a detailed writing developed via negotiations among sophisticated business entities and their advisors" is sufficient to show that the plaintiff's reliance on information outside the final agreement was unreasonable); Rissman v. Rissman, 213 F.3d 381 (7th Cir. 2000) (holding the same); Jackvony v. RIHT Fin. Corp., 873 F.2d 411 (1st Cir. 1989) (holding the same).

6. 325 F.3d 174 (3d Cir. 2003), cert. denied, 540 U.S. 1068 (2003).

7. Id. at 183 .

8. The AES court did not distinguish between "sophisticated" and "unsophisticated" buyers in coming to this conclusion, although that court also noted that courts could consider the sophistication of buyers. Id. at 178-79.

9. Id. at 183 . 
contained in the final agreement was reasonable within the context of Rule 10b-5. An NRC cannot logically be a factor in Rule 10b-5's "reasonable reliance" analysis because an NRC cannot be evidence that a buyer's reliance on information outside the parties' final agreement was unreasonable, when it has yet to be determined if the NRC produces a waiver of Section 10(b) in the first place. Factoring an NRC into a reasonable reliance analysis thus produces a circular inquiry. ${ }^{10}$

Courts' interpretation of Section 29(a) has spurred questions regarding the effectiveness of NRCs. Is the insertion of an NRC enough to protect a seller of stock from liability under Rule 10b-5? If not, should the presence of an NRC at least be a factor to consider when evaluating the reasonableness of a buyer's reliance on information outside of a final purchase agreement? As the Supreme Court declined to review the Third Circuit's decision in AES, ${ }^{11}$ the resultant split in authority has produced varying answers to these questions. ${ }^{12}$ Part I of this Note discusses the operation of Section 29(a) within the context of Rule 10b-5. Part II describes the competing judicial views on the significance to be accorded to NRCs. Part III addresses the faulty premises upon which these competing views rest, and explains why NRCs are logically irrelevant for determination of reasonable reliance under Rule 10b-5. Lastly, Part IV will explain why use of the NRC should be abandoned altogether.

10. Per the language of Section 29(a), an NRC that produces a waiver of compliance with Section 10 (b) (via pleading requirements of Rule 10b-5) is "void." If an NRC is void, it should not be a factor in determining reasonable reliance under 10b-5. To determine if an NRC is void, it must first be determined whether the buyer can prove fraud under Rule 10b-5. To prove 10b-5 fraud, the buyer must show reasonable reliance on a material misstatement or omission by seller. Thus, the analysis for voidness of an NRC points to $10 \mathrm{~b}-5$ fraud - which points right back to the NRC to determine reasonable reliance, even though it has not been determined if the NRC is void. Thus, the factoring of an NRC into 10b-5's reasonable reliance inquiry is logically flawed.

11. See supra note 6.

12. Compare Citibank, N.A. v. Itochu Int'l Inc., No. 01 Civ. 6007, 2003 WL 1797847, at *1 (S.D.N.Y. Apr. 4, 2003) (precluding a plaintiff from claiming reasonable reliance on representations outside of the final written contract), with In re DaimlerChrysler AG, 294 F. Supp. 2d 616, 623 (D. Del. 2003) (quoting AES Corp. v. Dow Chemical Co., 325 F.3d 174, 180, 183 (3d Cir. 2003) for the proposition that "the existence of a non-reliance clause is [only] one factor to consider in determining the reasonableness of a party's reliance"), and Chase Manhattan Mortgage Corp. v. Advanta Corp., No. Civ.A.01-507, 2005 WL 2234608, at *20 (D. Del. Sept. 8, 2005) (quoting In re DaimlerChrysler AG, 294 F. Supp. 2d 616, 623 (D. Del. 2003)). 


\section{Section 29(a) Within the Context of Rule 10B-5}

Section 29(a) of the Exchange Act provides that "any condition, stipulation, or provision binding any person to waive compliance with any provision of this title or of any rule or regulation thereunder, or of any rule of an exchange required thereby shall be void." ${ }^{13}$ More succinctly, the United States Supreme Court has recognized that "the anti-waiver provision of Section 29(a) forbids [the] enforcement of agreements to waive 'compliance' with the provisions of the statute." 14 Thus, in order to state whether an NRC should be given legal effect under the Exchange Act, it must first be determined whether or not an NRC is an agreement that allows a defendant to waive compliance with any provision of the Exchange Act. ${ }^{15}$

Section 10(b) of the Exchange Act prohibits the "use or employ, in connection with the purchase or sale of any security ... [of] any manipulative or deceptive device or contrivance in contravention of such rules and regulations as the Commission may prescribe as necessary or appropriate in the public interest or for the protection of investors." ${ }^{\text {"16 }}$ To implement Section 10(b), the SEC promulgated Rule $10 \mathrm{~b}-5 .{ }^{17}$ In order to state a valid claim under Rule 10b-5, a plaintiff must show that the defendant "(1) made a misstatement or an omission of a material fact (2) with scienter (3) in connection with the purchase or the sale of a security (4) upon which the plaintiff reasonably relied and (5) that the plaintiff's reliance was the proximate cause of his or her injury." " Only the fourth factor (reasonable reliance) falls within the scope of this Note.

\footnotetext{
13. 15 U.S.C. $\$ 78 \mathrm{cc}(\mathrm{a})(2000)$.

14. Shearson/Am. Express Inc. v. McMahon, 482 U.S. 220, 228 (1987).

15. For purposes of this Note, the only provision of the Exchange Act that will be discussed is the antifraud provision of Section 10(b) as implemented by Rule 10b-5.

16. 15 U.S.C. $\S 78 \mathrm{j}(\mathrm{b})(2000)$.

17. 17 C.F.R. $\S 240.10 b-5$ (2003).

18. Semerenko v. Cendant Corp., 223 F.3d 165, 174 (3d Cir. 2000). See also Azrielli v. Cohen Law Offices, 21 F.3d 512, 517 (2d Cir. 1994) (quoting SEC v. Tex. Gulf Sulphur Co., 401 F.2d 833, 860 (2d Cir. 1968)) ("Rule 10b-5 . . makes unlawful any misrepresentation 'that would cause reasonable investors to rely thereon ...."'); Paracor Fin., Inc. v. Gen. Elec. Capital Corp., 79 F.3d 878, 886 (9th Cir. 1996) (quoting Atari Corp. v. Ernst \& Whinney, 981 F.2d 1025, 1030 (9th Cir. 1992)) ("Justifiable reliance 'is a limitation on a rule $10 \mathrm{~b}-5$ action which insures that there is a causal connection between the misrepresentation and the plaintiff's harm.'”); Harrison v. Dean Witter Reynolds, Inc., 79 F.3d 609, 618 (7th Cir. 1996) ("The fact of reliance . . is not enough by itself; that reliance must be justifiable, or reasonable.”); One-O-One Enters., Inc. v. Caruso, 848 F.2d 1283, 1286 (D.C. Cir. 1988) (“[P]laintiffs' allegations must indicate that their reliance on the allegedly fraudulent representations was reasonable.").
} 
The issue of reasonable reliance typically arises in two scenarios: First, when the plaintiff has relied on information that is contradicted by the definitive agreement; ${ }^{19}$ and second, when the plaintiff has relied on information (or omissions) that have not been included in the final written agreement, which contained an NRC. ${ }^{20}$ These scenarios occur because parties often wish to use NRCs as a contractual mechanism to limit the parties' representations to the four corners of the final contract, and preclude a party from claiming reliance on any information that has not been included in that contract. $^{21}$

Up to this point, there has been no clear rule for determining what exactly constitutes "reasonable" reliance. Many factors are examined to determine whether a plaintiff's reliance on certain representations is justified, such as: (1) whether a fiduciary relationship existed between the parties; (2) whether the plaintiff had the opportunity to detect the fraud; (3) the sophistication of the plaintiff; (4) the existence of long-standing business or personal relationships; (5) the plaintiff's access to all of the relevant information; (6) the opportunity to detect fraud; (7) whether the plaintiff initiated the stock transaction or sought to expedite the transaction; and (8) the generality or specificity of the misrepresentations. ${ }^{22}$ Thus, bearing these factors in mind, to determine whether a purchaser can bring suit under Rule 10b-5 (to allege violation of Section 10(b)), the following question must be determined: does a seller's inclusion of an NRC preclude a buyer from claiming that it reasonably relied on representations and warranties that were made during the course of negotiations, but which were not included in the parties' final written agreement?

\section{Competing Judicial Interpretations of the NRC's Significance}

Courts have answered the above question in different ways. ${ }^{23}$ While some courts have given dispositive weight to the presence of an NRC in a Rule

19. See, e.g., Kennedy v. Josephthal \& Co., Inc., 814 F.2d 798, 801 (1st Cir. 1987); Zobrist v. Coal-X, Inc., 708 F.2d 1511, 1514 (10th Cir. 1983).

20. See, e.g., Citibank, N.A. v. Itochu Int'l Inc., No. 01 Civ. 6007, 2003 WL 1797847, at *2 (S.D.N.Y. Apr. 4, 2003); One-O-One Enters., 848 F.2d at 1285.

21. See David K. Lutz, Note, The Law and Economics of Securities Fraud: Section 29(A) and the Non-Reliance Clause, 79 Chi.-Kent L. Rev. 803, 808 (2004).

22. AES Corp. v. Dow Chem. Co., 325 F.3d 174, 178-79 (3d Cir. 2003) (citing Straub v. Vaisman \& Co., 540 F.2d 591, 598 (3d Cir. 1976)); Kennedy, 814 F.2d at 804 (quoting Zobrist v. Coal-X, Inc., 708 F.2d 1511, 1514 (10th Cir. 1983)).

23. See cases cited supra note 12 . 
10b-5 "reasonable reliance" analysis, others have only accorded NRCs partial evidentiary value. ${ }^{24}$ Although each line of cases rests upon faulty premises, analysis of both is required to draw out their fallacies.

\section{A. The Harsco Standard}

Until 2003, the standard rule of law regarding NRCs was that the inclusion of such a clause would preclude a purchaser of stock from claiming that it reasonably relied on any representations or warranties that were not contained in the final agreement between the parties. ${ }^{25}$ In Harsco Corp. $v$. Segui ${ }^{26}$ the Second Circuit affirmed the dismissal of a plaintiff's Rule 10b-5 action based upon its alleged reliance on extra-contractual representations. ${ }^{27}$ The Court of Appeals reached this holding because the presence in the acquisition agreement of an NRC, together with fourteen pages of representations and warranties, established that the buyer could not have reasonably relied on any of the extra-contractual representations. ${ }^{28}$

In this case, the Harsco Corporation (hereinafter "Harsco") sued various former officers and shareholders of MultiServ, a company previously purchased by Harsco, under Rule 10b-5. ${ }^{29}$ Harsco alleged that "because the purchase price was $\$ 380$ million less the amount of certain debt, including project finance debt, [MultiServ] had a motive to misrepresent the extent to which new projects were completed." ${ }^{30}$ Harsco claimed that MultiServ made various misstatements during due diligence regarding projected business activity and expected developments in the business. ${ }^{31}$ Despite the fact that the parties entered into a purchase agreement that was subject to confirmatory due diligence, provided for extensive representations, and included an NRC and merger clause, Harsco argued that the non-reliance and merger clauses of the agreement should not bar the establishment of a claim under Rule $10 \mathrm{~b}-5 .{ }^{32}$

24. See id.

25. See, e.g., cases cited supra note 5; One-O-One Enters., Inc. v. Caruso, 848 F.2d 1283, 1287 (D.C. Cir. 1988) (quoting Tonn v. Philco Corp., 241 A.2d 442, 445 (D.C 1968)) ("Were we to permit plaintiffs' use of the defendants' prior representations (and defendants' nondisclosure of negotiations inconsistent with those representations) to defeat the clear words and purpose of the Final Agreement's integration clause, 'contracts would not be worth the paper on which they are written."').

26. 91 F.3d 337 (2d Cir. 1996).

27. Id. at 348 .

28. Id. at 344 .

29. Id. at 339 .

30. Id. at 341 .

31. Id.

32. Id. at 343 . 
According to Harsco, it reasonably relied upon a number of representations allegedly made by the sellers outside of the contract. ${ }^{33}$

In particular, the Harsco court concluded that the NRC at issue did not violate Section 29(a) of the Exchange Act because the buyer did not indiscriminately waive the protections afforded by Rule $10 \mathrm{~b}-5,{ }^{34}$ but instead limited to a reasonable degree the universe of statements (i.e., the fourteen pages of representations) in respect of which the buyer could assert a claim under Rule 10b-5. ${ }^{35}$ Therefore, under Harsco and its progeny, the inclusion of an NRC can establish, as a matter of law, that a plaintiff's reliance on information not included in the parties' the final agreement was unreasonable. $^{36}$ In other words, when an NRC is included in a detailed writing, and negotiated at arms' length between sophisticated parties, the Harsco rationale would consider that to be a sufficient showing to bar a plaintiff from succeeding in a Rule $10 \mathrm{~b}-5$ action on the basis that it reasonably relied on information not in the agreement. ${ }^{37}$

\section{B. The AES Standard}

In 2003, the Third Circuit Court of Appeals broke away from the traditional view of NRCs. ${ }^{38}$ In AES v. Dow Chemical Co.,${ }^{39}$ the court held that the existence of an NRC may only be considered as one piece of evidence-as opposed to being dispositive evidence - that a buyer unreasonably relied on information not contained in the final agreement. ${ }^{40}$

In this case, the AES Corporation (hereinafter "AES") claimed that Dow Chemical (hereinafter "Dow") and its subsidiary had violated Section 10(b) of the Exchange Act in a deal where AES bought the stock of Dow's subsidiary whose only asset was a contract to design and build a power plant in the Netherlands. ${ }^{41}$ AES claimed that Dow and its subsidiary made material misrepresentations about the power plant, as AES later realized that the plant would cost "far more to complete than [their] due diligence investigation had

33. Id.

34. See id.

35. Id.

36. See supra note 27.

37. See generally Harsco, 91 F.3d 337.

38. As previously mentioned, the "traditional view" of NRCs was the standard embodied by the Harsco decision and its progeny.

39. 325 F.3d 174 (3d Cir. 2003).

40. Id. at 180

41. Id. at 175 . 
indicated," and would not be operative until much later than Dow and its subsidiary had stated. ${ }^{42}$ Specifically, AES claimed that Dow violated Rule $10 \mathrm{~b}-5$, as it "knew specific facts about the [plant] that contradicted the representations [made] . . . during due diligence." ${ }^{\text {"3 }}$ Dow claimed that its inclusion of an $\mathrm{NRC}^{44}$ into the stock purchase agreement should preclude a finding that AES "reasonably relied" on any representations or warranties not contained in the final agreement. ${ }^{45}$

The majority opinion was not willing to go so far as to hold that the inclusion of an NRC would always preclude such a finding of reasonable reliance. ${ }^{46}$ Rather, it merely stated that a buyer will have to "show more to justify its reliance" if there is an NRC than if there is not one. ${ }^{47}$ The opinion also noted that in cases where sophisticated parties have negotiated a contract that includes an NRC, such cases "will often be appropriate candidates for ... summary judgment." 48

While AES and Harsco appear to stand for opposing propositions, ${ }^{49}$ they clearly share at least one common feature: to some degree, both of these cases view the presence of an NRC as having some impact on whether a buyer can claim that it reasonably relied on information that was external to the final stock purchase agreement. ${ }^{50}$ It is in this facet of their analyses that the flaw lies.

\section{Misinterpretation of Section 29(a), and a Proper Analysis}

The analyses set forth in Harsco and AES are flawed, as they respectively view the presence of an NRC as at least evidence of unreasonable reliance. ${ }^{51}$

\footnotetext{
42. Id. at 177 .

43. Id. at 178 .

44. The NRC used by AES read:
}

We [AES] further agree that we are not entitled to rely on the accuracy or completeness of the Information and that we will be entitled to rely solely on any representations and warranties as may be made to us in any definitive agreement with respect to the Transaction, subject to such limitations and restrictions as may be contained therein. Id. at 176 .

45. Id. at 180 .

46. See id.

47. Id. at 181 .

48. Id.

49. Insomuch as Harsco stands for the proposition that NRCs can preclude a finding, as a matter of law, of reasonable reliance on information external to the final contract-and AES stands for the proposition that NRCs can never preclude a finding, as a matter of law, of such reasonable reliance.

50. Compare AES, 325 F.3d at 183, with Harsco Corp. v. Segui, 91 F.3d 337, 346 (2d Cir. 1996).

51. See AES, 325 F.3d at 183; Harsco, 91 F.3d at 346. 
A defendant's inclusion of an NRC should be irrelevant for purposes of determining whether a seller's reliance on information not contained in the final agreement was reasonable under Rule 10b-5. An NRC cannot logically be a factor in Rule 10b-5's "reasonable reliance" analysis because such treatment of an NRC would give it effect before it is known whether or not the NRC is "void" within the meaning of Section 29(a).

\section{A. Proposed Standard}

Section 29(a) of the Exchange Act forecloses anticipatory waivers of compliance with any provision of the Act. Specifically, Section 29(a) states that "[a]ny condition, stipulation, or provision binding any person to waive compliance with any provision of this chapter or of any rule or regulation thereunder . . . shall be void." ${ }^{52}$ For purposes of this argument, this rule can be restated as such: NRCs that violate Section 29(a) are "void." 33 By the language of Section 29(a), an NRC is "void" if it allows a seller to waive compliance with Section 10(b).$^{54}$ To determine whether the NRC in question has allowed a seller to waive compliance with Section 10(b), a court must first determine whether the buyer can prove fraud under Rule 10b-5. ${ }^{55}$

In order to prevail on a Rule $10 \mathrm{~b}-5$ claim, a buyer must be able to prove that it "reasonably relied" on representations and warranties made by the seller during negotiations, but which were not included in the final written agreement. To prove reasonable reliance, courts look to factors such as the sophistication of the parties, any past relationship between them, and many others. ${ }^{56}$ This is where the flaw in the current analyses lies: How can an NRC be evidence that a buyer's reliance on information outside the parties' final agreement was unreasonable - when it has yet to be determined if the NRC is void because it produces a waiver of Section 10(b)?

52. 15 U.S.C. $\S 78 \mathrm{cc}(\mathrm{a})(2000)$.

53. Id.

54. "Any ... provision binding any person to waive compliance with [Section $10(\mathrm{~b})]$. . . shall be void." Id

55. "To state a valid claim under Rule 10b-5, a plaintiff must show that the defendant (1) made a misstatement or an omission of a material fact (2) with scienter (3) in connection with the purchase or the sale of a security (4) upon which the plaintiff reasonably relied and (5) that the plaintiff's reliance was the proximate cause of his or her injury." Semerenko v. Cendant Corp., 223 F.3d 165, 174 (3d Cir. 2000) (citing Weiner v. Quaker Oats Co., 129 F.3d 310, 315 (3d Cir. 1997); In re Burlington Coat Factory, 114 F.3d 1410, 1417 (3d Cir. 1997). This Note assumes, arguendo, that elements (1), (2), (3), and (5) are satisfied, and therefore only addresses element (4) reasonable reliance.

56. See supra note 22 and accompanying text. 
As previously stated, if an NRC produces a waiver of Section 10(b), then it is "void." "A void clause is 'of no effect whatsoever.' It is 'an absolute nullity.' It is 'ineffective,' 'useless,' 'having no legal force or validity." ${ }^{57}$ If the language of Section 29(a) is to be given effect, NRCs that produce waivers of Section 10(b) should be of absolutely no evidentiary value. In both Harsco and $A E S$, the courts, at the very least, viewed the presence of an NRC as evidence that a buyer's reliance on information outside of the agreement was unreasonable. ${ }^{58}$ By factoring the NRC into the 10b-5 "reasonableness" analysis before determining whether the NRC was "void," leaving open the possibility that a "void" NRC could be used in the analysis. Indeed, as Senior Circuit Judge Wallace stated in his concurring opinion in $A E S$, "[i]f we permit the void stipulation to have evidentiary value, . . . [i]t becomes a very potent weapon in the $10 \mathrm{~b}-5$ defendant's arsenal. This is precisely what section 29 (a) prohibits. ${ }^{\circ 60}$

The possibility that a "void" NRC will be considered in a Rule 10b-5 reasonable reliance analysis is the most persuasive reason why NRCs should be given no consideration in such analysis. But what if the NRC is not "void" (i.e., one that does not produce a waiver of compliance with any section or rule of the Exchange Act)? It makes no difference that it will not have been considered, because the defendant will have already won the case. Consider the following scenario.

Company A wishes to acquire its longtime supplier, Company B. Through the course of their negotiations, many oral and written representations, warranties, and projections are exchanged. ${ }^{61}$ In the final purchase agreement, which includes an NRC, Company B includes certain representations and warranties (we'll call them Representations 1, 2, 3, and 4). Assume further that both parties are considered to be sophisticated. Two months after having completed its purchase of Company B's stock, Company A begins losing millions on the deal. Upset with its plight, Company A sues Company B for violation of Section 10(b) of the Exchange Act, claiming that

57. AES Corp. v. Dow Chem., 325 F.3d 174, 184 (3d Cir. 2003) (Wallace, J., concurring in part and dissenting in part) (citing Black's Law Dictionary 1568 (7th ed. 1999); The American Heritage DiCTIONARY 911 (4th ed. 2001)).

58. See AES, 325 F.3d at 183; Harsco Corp. v. Segui, 91 F.3d 337, 346 (2d Cir. 1996).

59. 15 U.S.C. $\$ 78 \mathrm{cc}(\mathrm{a})(2000)$.

60. AES, $325 \mathrm{~F} .3 \mathrm{~d}$ at 184 (Wallace, J., concurring in part and dissenting in part).

61. For purposes of this hypothetical, assume all of this "soft" information provided by Company $\mathrm{B}$ is true, and that Company B has included all material facts both during their negotiations with Company $\mathrm{A}$, and in their final purchase agreement. 
it believes that Company B inflated their projections (let's call this projection Representation 5).

To determine whether the NRC allowed Company B to waive compliance with Section 10(b), it must be determined whether Company A can state a claim under Rule 10b-5. ${ }^{62}$ In order to resolve this inquiry, it must be determined whether Representation 5 was ever made; and if it was, whether Company A may be said to have reasonably relied upon it. Even if Representation 5 was found to have been made, most of the reasonableness factors which courts analyze in a Rule 10b-5 analysis speak against Company A's reasonable reliance. ${ }^{63}$ The parties here have a long-standing business relationship ${ }^{64}$ they have negotiated the final purchase agreement at arms' length, ${ }^{65}$ both parties were sophisticated, ${ }^{66}$ and presumably of equal bargaining power, ${ }^{67}$ and Company B has not attempted to conceal any fraud insomuch as it has been truthful in all of its representations and included all material facts in the agreement. ${ }^{68}$ For these reasons, the plaintiff will not prevail on its Rule 10b-5 claim, as the court will find that there was no basis for the suit.

Because of this, the NRC cannot be viewed to have allowed Company B to waive compliance with Section 10(b). But at this point, of how much importance is the existence of the NRC? To determine whether or not the NRC was "void," the court first has to go through the plaintiff's $10 \mathrm{~b}-5$ claim - the basis of the suit itself. Upon finding that Company A cannot state a claim under Rule 10b-5, the court would hold that Company B has not violated Section 10(b) ${ }^{69}$ Thus, it is of no consequence that the NRC was not void, because it requires the primary inquiry - whether a violation of Section 10(b) as implemented by Rule 10b-5 has occurred - to take place before it can even be determined whether or not the NRC is void.

This hypothetical illustrates that even a non-"void" NRC cannot ever be used as a factor in determining reasonable reliance. While a non-"void" NRC would be useful evidence of the buyer's reliance on outside information, its

62. For purposes of this hypothetical, as with the entirety of this Note, assume that Company A can prove that Company B (1) made a misstatement or an omission of a material fact (2) with scienter (3) in connection with the purchase or the sale of a security ... and (5) that the plaintiff's reliance was the proximate cause of his or her injury. Thus, the only issue being discussed is reasonable reliance.

63. See supra notes 22-30 and accompanying text.

64. See supra note 26 and accompanying text.

65. See supra notes 23,27 and accompanying text.

66. See supra note 25 and accompanying text.

67. See supra notes $23,25,27$ and accompanying text.

68. See supra notes $29-30$ and accompanying text.

69. See supra note 61 and accompanying text. 
usefulness is only realized after the buyer's reliance is evaluated under the reasonableness factors which courts have drawn from in the past. ${ }^{70}$ To the extent that Harsco and $A E S$ (and their respective progenies) weigh the existence of an NRC into the determination of a party's reasonable reliance on information outside the four corners of a document, ${ }^{71}$ their tests are incorrect. Instead of using NRCs as such evidence, they should be considered completely irrelevant for purposes of determining whether a party may be said to have reasonably relied on information not contained in the parties' final agreement. This analysis is required by the language of Section 29(a) of the Exchange Act, and its implementation would save courts from having to engage in such a circular inquiry.

\section{B. Latent Criticisms}

It may be argued that this standard, whereby NRCs are of no import in a $10 \mathrm{~b}-5$ reasonable reliance analysis, will lead to increased transaction costs, ${ }^{72}$ thereby lowering efficiency of the securities markets. ${ }^{73}$ This may well be the case, but it is not within a court's power to factor an NRC into the reasonable reliance analysis, when the language of Section 29(a) specifically forecloses such treatment.

Many policy-based arguments have been advanced regarding the proper scope of an NRCs influence. The primary dichotomy is between the law and economics school of thought ${ }^{74}$ and the behavioralist perspective. ${ }^{75}$ These arguments elucidate complex issues regarding the picture of a perfectly efficient market, ${ }^{76}$ the actual behavior of market participants, ${ }^{77}$ and to what extent these two views of the securities markets can coalesce. ${ }^{78}$ While courts

70. See AES Corp. v. Dow Chem., 325 F.3d 174, 178-79 (3d Cir. 2003) (citing Straub v. Vaisman \& Co., 540 F.2d 591, 598 (3d Cir. 1976)). See also Kennedy v. Josephthal \& Co., Inc., 814 F.2d 798, 804 (1st Cir. 1987); Zobrist v. Coal-X Inc., 708 F.2d 1511, 1516 (10th Cir. 1983).

71. Compare AES, 325 F.3d at 183, with Harsco Corp. v. Segui, 91 F.3d 337, 346 (2d Cir. 1996).

72. See Thomas S. Ulen, Rational Choice Theory in Law and Economics, in 1 ENCYClOPEDIA OF LAW AND ECONOMICS 790, 803 (Boudewijn Bouckaert \& Gerrit De Geest eds., 2000).

73. See id. See also Elaine A. Welle, Freedom of Contract and the Securities Laws: Opting Out of Securities Regulation by Private Agreement, 56 Wash. \& LeE L. Rev. 519 (1999).

74. See, e.g., Ulen, supra note 72, at 790; Richard A. Posner, The Economic Approach to Law, 53 TEx. L. Rev. 757, 761 (1975).

75. See, e.g., Robert Prentice, Contract-Based Defenses in Securities Fraud Litigation: A Behavioral Analysis, 2003 U. ILL. L. REV. 337.

76. See generally Posner, supra note 74.

77. See generally Prentice, supra note 75.

78. Cf. Posner, supra note 74; Prentice, supra note 75. 
often find such policy goals attractive when expounding the rationale for their decisions, ${ }^{79}$ these arguments are best suited for discussion among the Legislature and the Regulatory Commissions (i.e., the SEC) to which the Congress delegates rule-making authority.

Furthermore, it may be argued that traditional notions of freedom of contract mandate the ability to employ the use of contractual provisions such as NRCs. ${ }^{80}$ While the use of an NRC seems wholly permissible based on the freedom of contract principles upon which our capitalist society rests, such tenets must be cast aside in the face of legislation requiring an opposite conclusion. The Exchange Act requires parties to abstain from the sort of contracting embodied by the use of NRCs. As such, prohibiting use of NRCs should not be seen as compromising the maxim of freedom of contract, but rather as merely falling in line with the wishes of Congress. Surely the Legislature understood the importance of parties' ability to freely contract. Despite that importance, the Legislature decided to curb that ability in favor of protecting the integrity of the Exchange Act. ${ }^{81}$

\section{RETIRING THE NRC}

Parties include NRCs in their final stock purchase agreements in order to restrict the opposite party's ability to bring a fraud claim under Rule $10 \mathrm{~b}-5 .{ }^{82}$ Because NRCs should no longer be a factor in determining reasonable reliance in the context of Rule 10b-5, this goal is entirely frustrated. If including an NRC does nothing to protect a party from potential 10b-5 liability, then what is the point in using one? Based upon the foregoing analysis, there is none. Retiring NRCs from use will also have the following positive effect: less

79. See, e.g., Harsco Corp. v. Segui, 91 F.3d 337 (2d Cir. 1996) (exuding a law and economics flavor); AES Corp. v. Dow Chem., 325 F.3d 174 (3d Cir. 2003) (adopting more of a behavioralist approach).

80. See, e.g., Park McGinty, The Limited Liability Company: Opportunity for Selective Securities Law Deregulation, 64 U. CIN. L. REv. 369 (1996); Larry E. Ribstein, Form and Substance in the Definition of a "Security": The Case of Limited Liability Companies, 51 WaSH. \& LEE L. Rev. 807 (1994); Larry E. Ribstein, Private Ordering and the Securities Laws: The Case of General Partnerships, 42 CASE W. REs. L. REV. 1 (1992).

81. Indeed, other traditional principles upon which our country was founded have had exceptions carved out of them. For instance, while the First Amendment provides that "Congress shall make no law abridging the freedom of speech," the Supreme Court has held there to be exceptions to this broad principle, such as "fighting words" (see Chaplinsky v. New Hampshire, 315 U.S. 568, 572 (1942)), some forms of libel (see N.Y. Times Co. v. Sullivan, 376 U.S. 254, 267 (1964)), and "hate speech" (see Beauharnais v. Illinois, 343 U.S. 250, 261 (1952)).

82. 17 C.F.R. $\S 240.10 b-5$ (2003). 
instances of fraud via more complete disclosures during negotiations leading up to stock purchase agreements.

Fraud would be less prevalent in a world without NRCs. If parties are no longer able to rely on these Get-Out-of-Jail-Free cards, they will have only one alternative to employ in hopes of reducing their potential to be sued for a violation of Rule 10b-5: absolute honesty. Surely if a party is one-hundred percent honest in its dealings leading up to a sale, and those dealings are wellrecorded, it has nothing to fear should the other party decide to challenge it in court. It may be argued that this is a less efficient result than would occur with the use of an NRC. Again, while this argument may have practical merit, such arguments are more properly left to the Legislature.

Furthermore, "[a]t least where contracts of adhesion are concerned, there is little reason to believe that the written contract" including an NRC is the extent of the "parties' definitive agreement." ${ }^{83}$ What is more likely the case is that "one party drafted the form and the other side signed it." 84 Excluding NRCs from use will thus enhance the transparency in the parties' negotiations over terms to be included in and excluded from contracts, ${ }^{85}$ since sellers would no longer be able to throw a standard, unpersonalized contract at the buyer. ${ }^{86}$ Certainly it is an age-old tenet of contract law that the more parties negotiate over each term of a contract, the more accurately the contract will reflect each of their intentions. ${ }^{87}$ Again, while this would prolong the bargaining process, and likely cost more to the parties than if an NRC were able to be utilized, the Legislature has spoken its preference for investor protection-as opposed to contractual efficiency — within Section 29(a) of the Exchange Act. ${ }^{88}$

\section{CONCLUSION}

This Note has argued that a defendant's inclusion of a NRC is irrelevant for purposes of determining whether a plaintiff's reliance on information not contained in the final agreement was reasonable under Rule 10b-5. In a Rule 10b-5 analysis, the text of Section 29(a) requires determination of whether an

\footnotetext{
83. Prentice, supra note 75 , at 420 .

84. Id.

85. See id.

86. See id.

87. See Mark Pettit, Jr., Modern Unilateral Contracts, 63 B.U. L. Rev. 551, 583 (1983).

88. As NRCs may be "provision[s] binding [a] person to waive compliance with [a] provision of [Section 10(b)] or of [Rule 10b-5], the Legislature's decision to make such provisions "void" only speaks to its preference against such provisions being used-it does not pass on the importance of using them to increase transactional efficiency.
} 
NRC has produced a waiver of compliance with Section 10(b). To determine this, a plaintiff must prove, inter alia, that it reasonably relied on information that was not contained in the final agreement in question. Thus, there is no logical reason why an NRC should be dispositive of, ${ }^{89}$ or even "evidence of" 90 the reasonableness of a party's reliance on information outside the final agreement. The use of NRCs should be abandoned, as their validity hinges on the exact same inquiry that a court has to engage in for any Rule 10b-5 action: an inquiry into the reasonableness of a party's reliance on information not contained in the final agreement.

Courts are using the existence of NRCs as a proxy for expounding economic policy decisions. ${ }^{91}$ This is hardly the proper function of our courts, and it is certainly a function that is foreclosed by the language of Section 29(a). The text of Section 29(a) clearly requires that a court first determine whether an NRC has produced a waiver of compliance with another provision in the Act before it may be given any evidentiary value. ${ }^{92}$ Because this analysis is required before a court can use an NRC as a factor in its reasonable reliance analysis, there is absolutely no reason to include them in such an analysis. The primary reason why parties include NRCs in their contracts is to preclude the opposite party from bringing suit under Rule $10 \mathrm{~b}-5 .{ }^{93}$ Because NRCs should be irrelevant to Rule 10b-5 analyses, their use should be discontinued.

89. Harsco Corp. v. Segui, 91 F.3d 337, 346 (2d Cir. 1996).

90. AES Corp. v. Dow Chem., 325 F.3d 174, 184 (3d Cir. 2003) (Wallace, J., concurring in part and dissenting in part).

91. See supra note 79.

92. This is so per the language requiring a determination whether a NRC, as a "provision bind[s] any person to waive compliance with any provision of this [Act] ..." 15 U.S.C. $§ 78 \mathrm{cc}($ a) (2000).

93. See In re DaimlerChrysler AG, 294 F. Supp. 2d 616, 620 (D. Del. 2003). 